\title{
OPTIMIZATION OF TEMPERATURE AND TIME PYROLYSIS FROM WHITE CHARCOAL BRIQUETTE PRODUCTION OF WASTED OIL PALM SHELL AND ACACIA BARK WITH RSM METHOD
}

\author{
Kurniawan Edy Wibowo*, Amirta Rudianto \\ Politeknik Pertanian Negeri Samarinda, Indonesia \\ Budiarso Edy, Arung Enos Tangke \\ Faculty of Forestry, University of Mulawarman, Indonesia \\ *E-mail: edy wibowosmd@yahoo.com
}

\begin{abstract}
The potential of palm oil shell waste reaches $37.6 \%$ (14.9 million tons / year) with a total energy potential of 54.8 Giga Joules / year. This study aims to determine optimization the temperature and time of pyrolysis of white charcoal production from palm oil shell waste and acacia bark waste with surface response method (RSM). The research was conducted in two stages. The first stage is the production of oil palm shell briquettes. Palm shells are reduced in size to 60 mesh mixed with $7 \%$ tar, then pressured $(200 \mathrm{~kg} / \mathrm{cm} 2)$. The next step is pyrolysis at $600^{\circ} \mathrm{C}, 700^{\circ} \mathrm{C}, 800{ }^{\circ} \mathrm{C}$ for 2,4 and 6 hours. White charcoal briquette products are analyzed by calculating fixed carbon content, water content, volatile matter content, ash content, and calorific value. Then an optimization is carried out with the surface response method (RSM) in order to obtain optimal conditions for the production of white charcoal briquettes from palm oil shell waste and acacia bark. The results showed that the optimal production of the pyrolysis conditions of oil palm shell briquettes was at $780.8^{\circ} \mathrm{C}$ for 5.25 hours. White charcoal briquettes that are produced under optimal conditions have characteristics of $81.57 \%$ fixed carbon content, $2.78 \%$ volatile matter content, $1.7 \%$ moisture content, $13.73 \%$ ash content, and calories value $7190.99 \mathrm{KCal} / \mathrm{kg}$.
\end{abstract}

\section{KEY WORDS}

Pirolysis optimization, white charcoal, oil palm shell, acacia bark.

Indonesia is one of the world's leading producers of oil palm. It is estimated that the area of oil palm plantation is about 14,6 million ha (Pertanian, 2018), producing 42,8 million tons of palm oil by 2020 (Miettinen et al, 2012).

Industries of pulp and wood chip discard waste as bark. Acacia bark (Acacia mangium) has not been yet properly utilized. The potential of producing bark is $10 \%$ to $20 \%$ from the trunk. Bark waste can be used in the form of tannins that contain in acacia bark. Tannins, according to some studies, are useful for gluing. Based on the results of acacia bark extract, it contains $40 \%$ (Batubara et al, 2005) or 37.9\% of tannin (Santoso, 2005) (Feng et al, 2013).

Currently, oil palm biomass is converted into various value-added products through various technologies. The oil palm mill generally used $98.4 \%$ of mesokarp fiber/ MF and $62.4 \%$ of palm kernel shell/ PKS as a boiler fuel source to generate electricity and steam for palm oil extraction, and a portion of MF (1.6\%) and PKS (37.6\%) are going to be commercialized. Oil palm shells are potential biomass products because of high value of calorific (17-19 GJ/ton) (Kong et al, 2014). Moreover, the oil palm mill leaves $37.6 \%$ of the oil palm shell that can be used as a renewable energy resource.

Utilization of oil palm shells waste into renewable energy sources in the form of white charcoal briquette is one of the alternatives of oil palm kernel waste utilization. However, the use of tapioca adhesive in the manufacture of briquettes, which is not resistant to high temperatures results in the adhesive function on white charcoal briquettes destruction (Kurniawan, 2010). Therefore, acacia bark can be alternative as adhesive matter (Feng et al., 2013) (Santoso, 2005) (Subyakto, 2003). 
The waste of oil palm shells contains large amounts of lignin (50.7\%) (Kong et al., 2014) as well as acacia bark which has $14.7 \%$ of lignin content. High lignin content at high temperature of pyrolysis decomposes and increases the carbon content bounded in the briquette (Hoong et al, 2011). The content of tannins contained in the acacia bark is able to act as adhesive matter. This is caused by the polyphenolic structure of the condensed tannins explains its reactivity as the basic of resins and high carbon content. Tannin-based thermoset resins indeed do not melt when it is heated. The materials shrink during pyrolysis, and resulted in cellular carbons with bulk densities and porous structures identical to those of their organic recovered precursors. Therefore, tannin is able to function as a heat-resistant adhesive, which transforming more of porous briquette structure. This is a common characteristic of charcoal and briquette (Celzard et al., 2015).

This study aims to determine the effect of optimum temperature and time on white charcoal briquette produce from oil palm shell waste and acacia bark with surface surface method (RSM).

Basic materials of this study are oil palm shell and acacia bark. Another material in the produce of briquettes are tars, chemicals components for the producing of briquettes and chemical analysis. High temperature of pyrolysis equipment like muffle furnace, hammer mill, briquette molding are used, and tools for analyzing physical properties, such as bomb calorimeter and glassware for chemical properties analysis.

The first phase of white charcoal briquettes is produced from oil palm shells waste and acacia bark. Oil palm shell waste and acacia bark are reduced to 60 mesh then mixed with $7 \%$ of pitch (from the weight of charcoal) (Kurniawan et al, 2017). Then, it is proceeded with briquette molding of $200 \mathrm{~kg} / \mathrm{cm}^{2}$.

The next phase of the white charcoal briquette produce is pirolysized at high temperature $\left(600,700,800{ }^{\circ} \mathrm{C}\right)$ for $2,4,6$ hours. The obtained white charcoal was analyzed in fixed carbon content, moisture content, volatile matter content, ash content, and caloric value. The data is optimized with response surface method (RSM) to obtain optimum condition to produce white charcoal briquette from oil palm shell waste and acacia bark.

\section{RESULTS AND DISCUSSION}

The fixed carbon content is used as the main parameter of a briquette or charcoal, reflecting its calorific value. The value fixed carbon content of white charcoal is shown on Table 1.

Table 1 - Value fixed carbon content of white charcoal (\%)

\begin{tabular}{cccc}
\hline Temperature $\left({ }^{\circ} \mathrm{C}\right)$ & \multicolumn{3}{c}{ Time of pyrolysis (hour) } \\
\cline { 2 - 4 } & 2 & 4 & 6 \\
\hline 600 & 72,04 & 79,08 & 76,38 \\
700 & 74,99 & 80,17 & 80,82 \\
800 & 76,11 & 81,57 & 78,08 \\
\hline
\end{tabular}

The results of the research continued with optimization of white charcoal production process with maximum fixed carbon content by Statistica 6.0 and Mathlab 7.0. Figure 1 shows the measurement of optimum condition.

Figure 1 presents white charcoal briquette production with maximum fixed carbon of $81,57 \%$ from pyrolysis at $780,8{ }^{\circ} \mathrm{C}$ for 5,25 hours. Eigen point results are $\lambda_{1}=-3,9176$ and $\lambda_{2}$ $=-1,4158$. Negative value of eigen indicates the maximum level of optimum point.

The fixed carbon content of charcoal and charcoal briquettes ranges from $50 \%$ to $95 \%$. Fixed carbon is the most important constituent of charcoal and or charcoal briquettes. This is due to reduced iron oxide to iron from charcoal in the metallurgical industry. Regarding its function as fuel, any bonded carbon will change its form to carbon dioxide by releasing energy (Grover and Mishra, 1996).

The measured fixed carbon content of $81.57 \%$, the white charcoal briquette produced in this study approached the traditional white charcoal fixed carbon value of $89.83 \%$ 
(Agriculture Organization Of The United Nations, 1983). In addition, it includes high quality charcoal with minimum carbon content requirement, which is $75 \%$ (Grover and Mishra, 1996).

The difference in yields, especially the fixed carbon content, is due to different base materials. In traditional white charcoal production used whole wood, usually from oak wood, which is very hard. Very hard wood contains many lignin, and when it is pirolysized at 350$500{ }^{\circ} \mathrm{C}$, it results in lignin decomposition into tar. This tar wraps the charcoal so that the contact of oxygen will be minimize. When in high temperature, oxygen on pyrolysis will burn the charcoal and produce ash so that the fixed carbon content is low (Duc et al, 2013) (Chia et al., 2014) (Kurniawan et al., 2017).
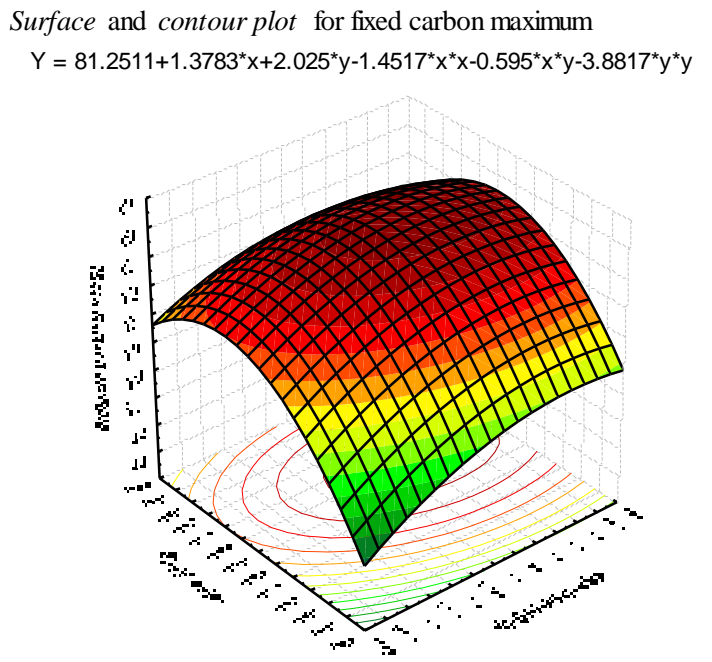

Temperature $-1\left(600{ }^{\circ} \mathrm{C}\right) ; 0\left(700{ }^{\circ} \mathrm{C}\right) ; 1\left(800^{\circ} \mathrm{C}\right)$

Time -1 ( 2 hours); 0 (4 hours); 1 (6 hours)

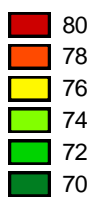

Figure 1 - Surface and contour plot for fixed carbon maximum

According to Gua and Lua (Guo and Lua, 2000), as the pyrolysis temperature increases, the volatile material in the pore structure of the carbon can be removed from materials of low molecular weight to high. The removal of this material will increase the carbon content per unit of dry weight. Similarly, the longer the pyrolysis time, will provide an opportunity for the heat penetrate the inside part of material. Consequently, it can remove more volatile substances. This de-volatilization process will increase the fixed carbon content in charcoal per unit weight (Kurniawan, 2010).

White charcoal product at optimum condition at temperature $780,8{ }^{\circ} \mathrm{C}$ for 5,25 hours with fixed carbon content $81,57 \%$. Other parameters such as volatile matter content, moisture content, ash content and caloric value under optimum conditions are calculated by entering the optimum temperature and time in the $Y$ canonical equation of each parameter obtained from the calculation by response surface method. The canonical equation:
a. Fixed carbon
b. Moisture content
c. Volatil substance
d. Ash content
e. Caloric point

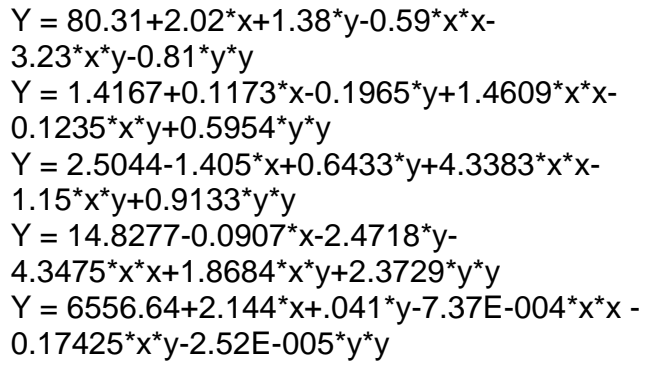


Therefore, another parameter value for white charcoal result of research at optimum condition is obtained: fixed carbon content (81.57\%), volatile matter content $(2.78 \%)$, moisture content $(1.7 \%)$, ash content $(13.73 \%)$, calorific value $(7190.99 \mathrm{KCal} / \mathrm{kg})$.

The white charcoal volatile matter content required in trading was $5.21 \%$ (Agriculture Organization Of The United Nations, 1983) so that white charcoal produce in this research is below that value, which is $2.78 \%$. With these low volatile substances, it will produce clean runing gas or very little smoke.

The moisture content white charcoal required in trading is $2.31 \%$. Therefore, white charcoal products in this study still meet the standard, which is $1.7 \%$ (Agriculture Organization Of The United Nations, 1983).

The ash content white charcoal required in trading is $1.82 \%$, while white charcoal product in this research above the standard (14.23\%). According to Guo and Lua (Guo and Lua, 2000), the level of charcoal from palm shells ranged from 9.1 to $19.5 \%$ so that the white charcoal product in this study, although far from the trade standard, is still within the range of ash content of oil palm kernel.
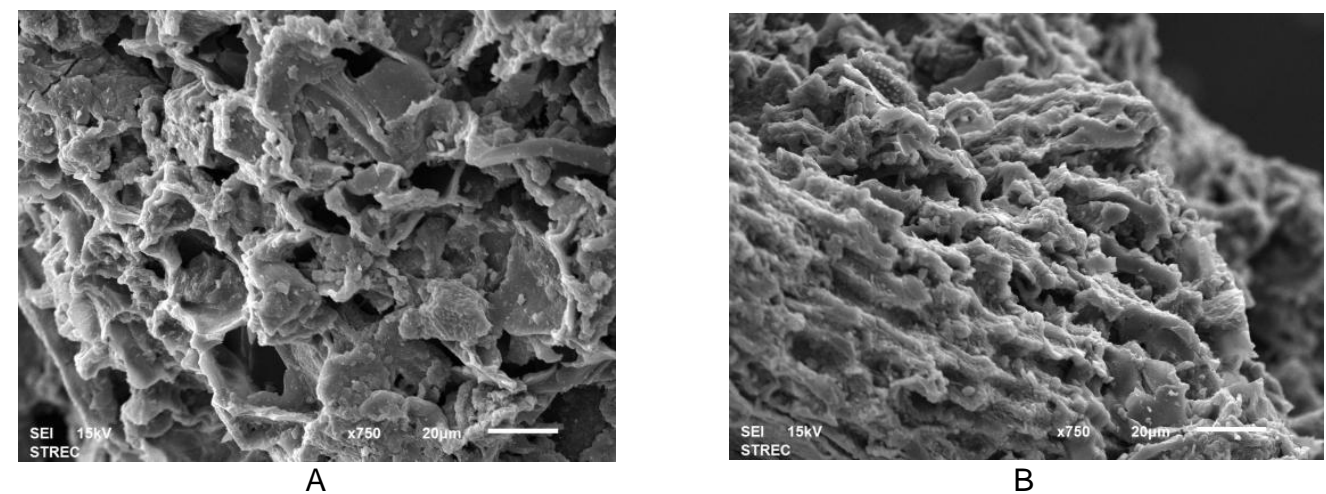

Figure 2 - (A) SEM images acquired from a typical white charcoal briquette particle;

(B) A high magnification secondary electron image of the white charcoal's briquette binding at magnification $20 \mu \mathrm{m}$

Figure 2 shows a series of SEM images obtained from white charcoal briquette particles. High magnification secondary electron images $(20 \mu \mathrm{m})$ reveal the structure of white charcoal particles with pores appearing parallel to all parts and bonds of the briquette of the tannin-lignin system making briquettes able to remain strongly bonded even though they are hydrolyzed at high temperatures. Thus, the lignin derived from palm shell waste is strongly bound to tannins from acacia bark waste, as in Fig. 2 (Subyakto, 2003; Wang and Bai, 2014).

\section{CONCLUSION}

Temperature and pyrolysis time on white charcoal briquette production is optimum at $780.8^{\circ} \mathrm{C}$ for 5,25 hours. Characteristic of white charcoal at optimum condition with fixed carbon content $81.57 \%$, volatile matter content $2.78 \%$, moisture content $1.7 \%$, ash content $13.73 \%$, and caloric value $7190.99 \mathrm{KCal} / \mathrm{kg}$.

It is suggested to design a pyrolysis tool that can withstand up to very high temperatures, e.g. over $1000^{\circ} \mathrm{C}$, with tightly sealed. Further research is needed on the mechanism of tannin-lignin bonding of white charcoal briquettes.

\section{ACKNOWLEDGEMENTS}

The researchers would like to thank DRPM Kemenristek Dikti for giving financial support to this research, with an agreement number of 049/SP2H/LT/DRPM/2018. 


\section{REFERENCES}

1. Agriculture Organization of the United Nations. Forestry Dept, \& Agriculture Organization of the United Nations. Mechanical Wood Products Branch. (1983). Simple Technologies For Charcoal Making (Vol. 41). Food \& Agriculture Org.

2. Batubara, R., Rosamah, E., \& Budiarso, E. (2005). Identifikasi Sifat Ekstrak Kulit Kayu Medang Hitam (Cinnamomum porrectum Roxb.) Sebagai Bahan Pengawet Kayu (Doctoral dissertation, Tesis Program Pasca Sarjana Universitas Mulawarman, Samarinda).

3. Celzard, A., Szczurek, A., Jana, P., Fierro, V., Basso, M. C., Bourbigot, S., Pizzi, A. (2015). Latest progresses in the preparation of tannin-based cellular solids. Journal of Cellular Plastics, 51(1), 89-102. https://doi.org/10.1177/0021955X14538273.

4. Chia, C. H., Joseph, S. D., Rawal, A., Linser, R., Hook, J. M., \& Munroe, P. (2014). Microstructural characterization of white charcoal. Journal of Analytical and Applied Pyrolysis, 109, 215-221. https://doi.org/10.1016/j.jaap.2014.06.009.

5. Duc, L., Morishita, K., \& Takar, T. (2013). Catalytic Decomposition of Biomass Tars at Low-Temperature. Biomass Now - Sustainable Growth and Use. https://doi.org/10.5772/55356.

6. Feng, S., Cheng, S., Yuan, Z., Leitch, M., \& Xu, C. (2013). Valorization of bark for chemicals and materials: A review. Renewable and Sustainable Energy Reviews, 26, 560-578. https://doi.org/10.1016/j.rser.2013.06.024.

7. Grover, P. D., \& Mishra, S. K. (1996). Biomass Briquetting: Technology and Pratices. Regional wood energy development program in Asia, field document no. 46. Bangkok, Thailand: Food and Agriculture Organization of the United Nations; (46).

8. Guo, J., \& Lua, A. C. (2000). Effect of Heating Temperature on The Properties of Chars and Activated Carbons Prepared from Oil Palm Stones. Journal of Thermal Analysis and Calorimetry, 60(2), 417-425. https://doi.org/10.1023/A:1010137308378.

9. Hoong, Y. B., Paridah, M. T., Loh, Y. F., Jalaluddin, H., \& Chuah, L. A. (2011). A new source of natural adhesive: Acacia mangium bark extracts co-polymerized with phenolformaldehyde (PF) for bonding Mempisang (Annonaceae spp.) veneers. International Journal of Adhesion and Adhesives, 31(3), 164-167. https://doi.org/10.1016/j.ijadhadh.2010.12.002.

10. Kong, S. H., Loh, S. K., Bachmann, R. T., Rahim, S. A., \& Salimon, J. (2014). Biochar from oil palm biomass: A review of its potential and challenges. Renewable and Sustainable Energy Reviews, 39, 729-739. https://doi.org/10.1016/j.rser.2014.07.107.

11. Kurniawan, 2010. Studi Suhu and Waktu Yang Optimal Pada Produksi Arang Putih Dari Arang Limbah Cangkang Kelapa Sawit, Prosiding Seminar Nasional Nasional (ISBN .978-602-95436-3-6), 2010.

12. Kurniawan, Edy Wibowo, Amirta, R., Budiarso, E., \& Arung, E. T. (2017). Mixing of acacia bark and palm shells to increase caloric value of palm shells white charcoal briquette. AIP Conference Proceedings, 1854. https://doi.org/10.1063/1.4985412.

13. Miettinen, J., Hooijer, A., Tollenaar, D., Page, S., \& Malins, C. (2012). Historical Analysis and Projection of Oil Palm Plantation Expansion on Peatland in Southeast Asia. Indirect Effects of Biofuel Production, (17), 1-49.

14. Pertanian, D. J. P. K. (2018). Statistik Perkebunan Indonesia Komoditas Kelapa Sawit 2017-2019.

15. Santoso, A. (2005). Pemanfaatan Lignin and Tanin Sebagai Alternatif Substitusi Bahan Perekat Kayu Komposit. Jurnal Teknologi Hasil Hutan, Vol. 14, pp. 7-15.

16. Subyakto, P. B. (2003). Direct Utilization of Acacia Bark Powder as Adhesive for Particleboard. Journal of Tropical Wood Science and Technology, 1(1), 20-25.

17. Wang, Y., \& Bai, X. (2014). Optical microscopy analysis of briquette binders. International Journal of Coal Science and Technology, 1(4), 421-427. https://doi.org/10.1007/s40789015-0051-8. 